\title{
Construction Quantification Achievement: The Effect of Individual Cognitive Ability and Demographic Differences
}

Norhafizah Yusop, Ismail Samsuddin, Mohmad Mohd Derus and Puteri Rohani Megat Abdul Rahim

To Link this Article: http://dx.doi.org/10.6007/IJARBSS/v12-i1/12355

DOI:10.6007/IJARBSS/v12-i1/12355

Received: 09 November 2021, Revised: 11 December 2021, Accepted: 07 January 2022

Published Online: 24 January 2022

In-Text Citation: (Yusop et al., 2022)

To Cite this Article: Yusop, N., Samsuddin, I., Derus, M. M., \& Rahim, P. R. M. A. (2022). Construction Quantification Achievement: The Effect of Individual Cognitive Ability and Demographic Differences. International Journal of Academic Research in Business and Social Sciences, 12(1), 2760-2772.

Copyright: (c) 2022 The Author(s)

Published by Human Resource Management Academic Research Society (www.hrmars.com)

This article is published under the Creative Commons Attribution (CC BY 4.0) license. Anyone may reproduce, distribute, translate and create derivative works of this article (for both commercial and non0-commercial purposes), subject to full attribution to the original publication and authors. The full terms of this license may be seen at: http://creativecommons.org/licences/by/4.0/legalcode

Vol. 12, No. 1, 2022, Pg. $2760-2772$

Full Terms \& Conditions of access and use can be found at http://hrmars.com/index.php/pages/detail/publication-ethics 


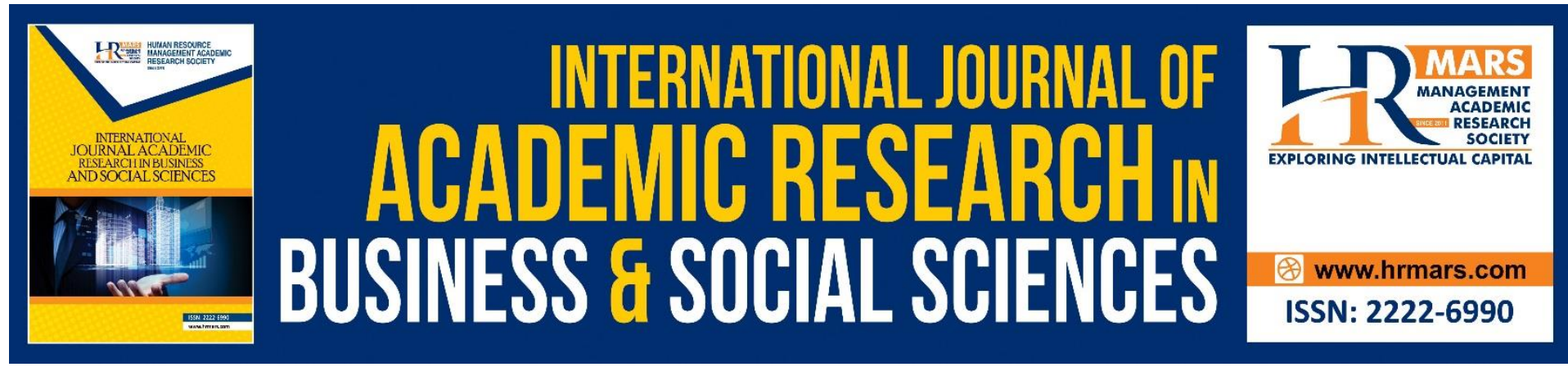

\title{
Construction Quantification Achievement: The Effect of Individual Cognitive Ability and Demographic Differences
}

\author{
Norhafizah Yusop ${ }^{1}$, Ismail Samsuddin², Mohmad Mohd Derus ${ }^{3}$ \\ and Puteri Rohani Megat Abdul Rahim ${ }^{4}$ \\ 1, 2, 3 Department of Built Environment Studies and Technology, Faculty of Architecture, \\ Planning and Surveying, Universiti Teknologi MARA, Perak Branch, 32610 Seri Iskandar, \\ Perak, Malaysia, ${ }^{4}$ Academy of Language Studies, Universiti Teknologi MARA, Perak Branch, \\ 32610 Seri Iskandar, Perak, Malaysia
}

\begin{abstract}
In responding to the construction quantification learning effect and academic achievements of the quantity surveying learners, the study examines the effects of several potential characteristics concerning specific individual differences such as cognitive abilities and demographics. Specifically, the study aims to compare the effects of individual differences in cognitive thinking, such as low or high spatial visualisation abilities and the demographics of learners (gender and age), towards the construction quantification achievement. The target respondent would be the quantity surveying learners (potential semi-professional graduates) in Malaysian public institutions. This preliminary study used a quantitative approach to determine the critical factors and indicators that lead to learners' moderate performance in the construction quantification course. A significant relationship between spatial visualisation ability (SVA) and the construction quantification achievement concludes that spatial intelligence serves as a framework to support people facing difficulties interpreting 2dimensional (2D) graphics representation. Seemingly, SVA is crucial to be possessed by the potential learners who wish to enrol in the quantity surveying programme. To successfully function and become more independent construction quantification learners in quantity surveying technical disciplines programme, these people need to have more spatial ability. However, there are no significant differences between different gender and age learners categories in spatial visualisation ability test (SVAT) scores and the construction quantification test (CQT) scores as the findings were insignificant. The result obtained in this study hoped to clarify the importance of cognitive ability and demographic differences to the construction quantification achievement.
\end{abstract}

Keywords: Effect, Achievement, Individual Differences, Cognitive Ability, Demographics.

\section{Introduction}

Besides architectural and engineering disciplines, the quantity surveying educational programme also rely on spatial visualisation ability (SVA) during the academic training. Although the quantity surveying scope of work is not about designing the technical drawing 
(construction plan), the core learning of the technical course, namely, construction quantification, requires the learners to interpret the technical drawing during the quantification process. To successfully function and quantify the quantities of the items shown in the technical drawings accurately, the profession (quantity surveying scope of work) requires future graduates to fully understand all the construction details (elements, items, descriptions) presented in a conventional 2-dimensional (2D) technical drawing (Fortune, \& Skitmore, 1993; Fortune, \& Skitmore, 1994). The knowledge requirements are essential for the quantity surveying profession and future graduates' future employment (Ali et al., 2016; Mohd-Derus et al., 2009). Therefore, to fully understand the technical drawing, it is crucial to ensure that all learners can read and interpret the 2D drawings prepared by the architect or engineer. Generally, when reading the $2 \mathrm{D}$ drawing, it is not explicitly limited to seeing the construction details in a 2D representation directly, but the learners need to view it mentally in 3-dimensional (3D) representation.

Essentially, it is beneficial for future graduates to possess the required cognitive skill. Prior theorists defined this human cognitive skill as an imagination to visualise, view mental images, sway, swivel, change and convert 2D or 3D visual stimuli (McGee, 1979). Generally, visualisation skills are crucial aspects of spatial ability (Carroll, 1993; McGee, 1979). The ability was crucial in several scientific and engineering activities (Wang et al., 2007). Similarly, in construction quantification problem-solving activities, there was also a requirement for the learners to visualise and rotate designs in 3D. To quantify precise quantities from the 2D technical drawing representation, they need to see all the construction details, which conventional 2D drawings cannot provide. Thus, it is beneficial to transform the 2D view into $3 \mathrm{D}$ because visualising and rotating the drawing would allow them to see more details that were limited presented from the conventional 2D drawing (Osman et al., 2015).

In construction quantification academic training (education), seemingly novice learners experienced difficulties performing a complicated visualisation task required during reading and translating drawings due to having a lack of imagination skills (Olkun, 2003). In addition, many novice learners struggled and had difficulties understanding the principles of construction quantification calculations due to limited knowledge and experience in construction technology practice. Lack of experience and exposure to construction technology has caused them to have limited cognitive thinking ability to visualise drawings correctly. Furthermore, a lack of proficiency in construction technology can cause learners to fail to interpret construction details and comprehend what is being measured (McDonnell, 2010). Consequently, to respond to the learning problem of the quantity surveying learners, this preliminary assessment focussed on several characteristics exploration concerning individual differences of cognitive thinking abilities, demographics and construction quantification academic achievements.

\section{Literature Review}

As previously described, construction quantification is a recognised course for quantity surveying technical programme learners. Past research claimed that spatial visualisation ability (SVA) is one of the critical human intelligence structures that need to be mastered by the learners as it is one of the critical factors involved when dealing with a problem-solving task that needs to deal with drawing interpretation (Fortune \& Skitmore, 1993; Fortune \& 
Skitmore, 1994). Furthermore, a previous study claimed that besides SVA, it is essential to consider several other significant factors when dealing with learning and performance issues.

Additionally, individual differences under two conditions, cognitive (spatial visualisation) and demographic differences (gender and age), were also reported to affect academic achievement significantly. Thus, in getting a reliable verification, a study that observed spatial visualisation ability (SVA), gender and age differences is needed to examine the extent to which these conditions contributed to educational achievement.

\section{Cognitive and Demographic Differences}

Previous theorists claim that cognitive abilities can affect learners' learning and academic achievement, mainly technical academic training involving designing or dealing with technical drawing (Olkun, 2003). Furthermore, in the previous research, many researchers agreed that possessing the necessary cognitive thinking abilities (spatial visualisation) and demographics can affect learners' learning and academic achievement. Additionally, prior research reveals that these critical characteristics of individual differences were significantly valued, especially for learners undergoing technical academic training involved in designing technical drawings.

In reality, did individual cognitive ability and demographics contribute to construction quantification learning and performance? To identify whether learning experience can be problematic or not, especially for novices, it seems crucial to determine whether there is a positive relationship between the research variables. In getting the answers, this study thoroughly examined every quality concerning benefits and corresponding values of individual differences to encourage better academic achievements amongst quantity surveying learners and future graduates. In tackling the construction quantification learning problem, it is essential to have a structured educational training guideline that addresses the critical factors of quantification proficiency. Specifically, identifying the characteristics of the individual differences, such as cognitive abilities, demographics nature, and significant relationships from prior studies, enables the findings to provide a valuable parameter to deal with the current learning problem of learners' achievements (proficiency) in the construction quantification. Furthermore, the review of findings obtained from the prior research (Table 1) can also suggest potential ideas for determining some critical indications related to the significant relationship between individual cognitive abilities, student demographics, and the quantification achievement of the recent quantity surveying learners. 
Table 1. Summary of Literature Review

\begin{tabular}{|c|c|c|}
\hline Author & Research Question & Core Inquiry \\
\hline $\begin{array}{l}\text { - } \text { Cassidy (2004) } \\
\text { - Inan \& Lowther (2010) } \\
\text { - Merchant et al (2013) } \\
\text { - } \text { Mokhtar \& Din (2013) } \\
\text { - Morris (2018) } \\
\text { - } \text { Novak (2010) } \\
\text { - } \text { Bidin (2014) }\end{array}$ & $\begin{array}{l}\text { What are the students' } \\
\text { specific characteristics? }\end{array}$ & \multirow[t]{6}{*}{$\begin{array}{l}\text { - Individual } \\
\text { Differences } \\
\text { - } \text { Cognitive } \\
\text { Ability } \\
\text { - Demographic } \\
\text { - Academic } \\
\text { Achievement }\end{array}$} \\
\hline $\begin{array}{l}\text { - Arslan and Dazkir (2017) } \\
\text { - Ben-Chaim et al (1986) } \\
\text { - Börner et al (2016) } \\
\text { - Galesic and Garcia-Retamero (2011) } \\
\text { - Golledge and Stimson (1997) } \\
\text { - Lee et al (2017) } \\
\text { - McGee (1979) } \\
\text { - Osman et al (2015) }\end{array}$ & $\begin{array}{l}\text { How do different individuals } \\
\text { fit into the construction } \\
\text { quantification problem- } \\
\text { solving ability? }\end{array}$ & \\
\hline \multirow{2}{*}{$\begin{array}{l}\text { - } \text { Ben-Chaim, Lappan and Huoang } \\
\text { (1988) } \\
\text { - Morris (2018) } \\
\text { - Park \& Yoon (2012) } \\
\text { - Ramful and Lowrie (2015) } \\
\text { - Robichaux and Guarino (2000) } \\
\text { - Salthouse et al (1990) }\end{array}$} & $\begin{array}{l}\text { How do gender and age } \\
\text { differences affect academic } \\
\text { achievement? }\end{array}$ & \\
\hline & $\begin{array}{l}\text { How do males and females } \\
\text { vary in terms of spatial } \\
\text { visualisation ability? }\end{array}$ & \\
\hline \multirow{2}{*}{$\begin{array}{l}\text { - Atan Long (1980) } \\
\text { - Hunter (1986); McGee (1979) } \\
\text { - Paivio (1990) } \\
\text { - Witkin (1973) } \\
\text { - Witkin et al (1977) }\end{array}$} & $\begin{array}{l}\text { How do differences affect } \\
\text { academic achievement? }\end{array}$ & \\
\hline & $\begin{array}{l}\text { What data should be } \\
\text { collected to determine } \\
\text { learning and performance } \\
\text { criteria? }\end{array}$ & \\
\hline
\end{tabular}

Essentially, the possible indicator obtained from the literature can help the present study be aware of any other critical factors that could jeopardise the construction quantification achievement of future graduates. Therefore, as shown in Table 1, the following research questions have been recognised to guide this present study:

1. What are the students' specific characteristics?

2. How do different individuals fit into the construction quantification problem-solving ability?

3. How do gender differences affect academic achievement?

4. How do males and females vary in spatial visualisation ability (SVA)?

5. How do age differences affect academic achievement?

6. What data should be collected to determine learning and performance criteria? 
This present study has determined several critical research questions relevant to core inquiries of individual differences, cognitive abilities, demographics, and academic achievement from the literature review findings. Although the paradigm of the previous research is not specifically in parallel with the present study, the potential indicator obtained from prior research can initially guide this research to consider the best research design and instrument options. Additionally, findings obtained from the multi-paradigm field are also beneficial in verifying whether the present study later could provide mutual findings or contradict research values.

\section{Research Methodology}

The preliminary study used a quantitative approach. This study involved a convenience sample of 40 learners from a well known public university who enrolled on the quantity surveying programme (Diploma) to justify the relationships and effect between different demographics, SVA levels, and the construction quantification course achievement. The sample of data involved semester four and six diploma learners in a public university due to practical reasons (availability). Moreover, to accomplish the research objective, Table 2 specifies the details of the research objective, instrument and method applied in this present study.

Table 2. Summary of Research Objective, Instrument and Method

\begin{tabular}{|l|l|c|}
\hline Research Objective & Research Instrument & Research Method \\
\hline $\begin{array}{l}\text { To determine the relationship } \\
\text { between SVAT scores and the } \\
\text { construction quantification } \\
\text { achievements }\end{array}$ & $\begin{array}{l}\text { 1. } \begin{array}{l}\text { Spatial Visualisation } \\
\text { Ability Test (SVAT) } \\
\text { Demographics } \\
\text { background } \\
\text { questionnaire survey } \\
\text { Construction } \\
\text { Quantification Test } \\
\text { (CQT) }\end{array} \\
\begin{array}{l}\text { To determine the effect of } \\
\text { gender and age differences on } \\
\text { the spatial visualisation ability } \\
\text { (SVA) and the construction } \\
\text { quantification achievements }\end{array}\end{array}$ & Quantitative \\
\hline
\end{tabular}

Generally, there were three instruments used during the data collection process. This preliminary study utilises a questionnaire survey, a psychometric test and an achievement test to assess the critical characteristics and factors related to the research questions. A questionnaire survey can help the study define individual respondents' profiles in the first stage. The demographics questionnaire also can categorise the learners' demographics based on gender and age differences.

Besides a questionnaires survey, another instrument opted to complete the second stage of the experimentation process. The instrument used is a psychometric test known as SVAT. Precisely, the SVAT instrument can determine whether research participants had low or high spatial visualisation ability (SVA).

In addition, to complete stage three of the research procedures, another testing instrument was used to be part of the test kits. The third instrument used during the final stage of the 
experimentation process is an achievement test known as CQT. The function of the test is to determine the performance levels of learners in the construction quantification course. Specifically, this study uses 2-dimensional (2D) and 3-dimensional (3D) technical drawings (construction plan). Generally, to ensure that CQT were acceptable for the experiment, the content and face validity of both CQT has been assessed and verified by the academic and construction industrial experts before usage.

\section{Findings and Discussion}

This quantitative study was analysed using descriptive and inferential statistics using the SPSS software. At the initial data analysis stage, the descriptive statistical analysis obtained from the SPSS results can specifically outline the nature of the data sample involved in this study into a specific type of learners categories. Furthermore, in this study, statistical analysis obtained from the SPSS results can determine specific differing characteristics of the participants in the sample. Specifically, the analysis results help answer factual questions related to the individual differences linked to several characteristics, such as demographics and cognitive abilities.

As previously described in the methodology section, after the learners answer a demographics background questionnaire survey and attempt the SVAT, they need to sit for an achievement test, namely the CQT. In this study, the results achieved from the SVAT scores and demographics background questionnaires can categorise the learners according to their specific individual differences. Initially, this study uses Pearson correlation analysis to determine whether there is any significant relationship between SVAT scores and CQT scores.

From the literature reviews, imagining and visualising construction details is considered as one of the essential factors and qualities for quantification skills (Fortune \& Skitmore, 1993). Many scholars agreed on the effects of SVA on learners' achievement. Similarly, the detailed analysis of the study found a significant relationship between the students' spatial visualisation ability (SVA) and their performance on the construction quantification. As shown in Figure 1, the coefficient of determination R2 of the SVA showed $65.3 \%$ of the variance in the construction quantification achievements. The scatterplot visual verified that the relationship between the SVA and the construction quantification achievement is linear. Furthermore, the findings show a significant linear relationship between SVA and construction quantification achievement as the linearity test result is less than $0.05(p<0.05)$. 


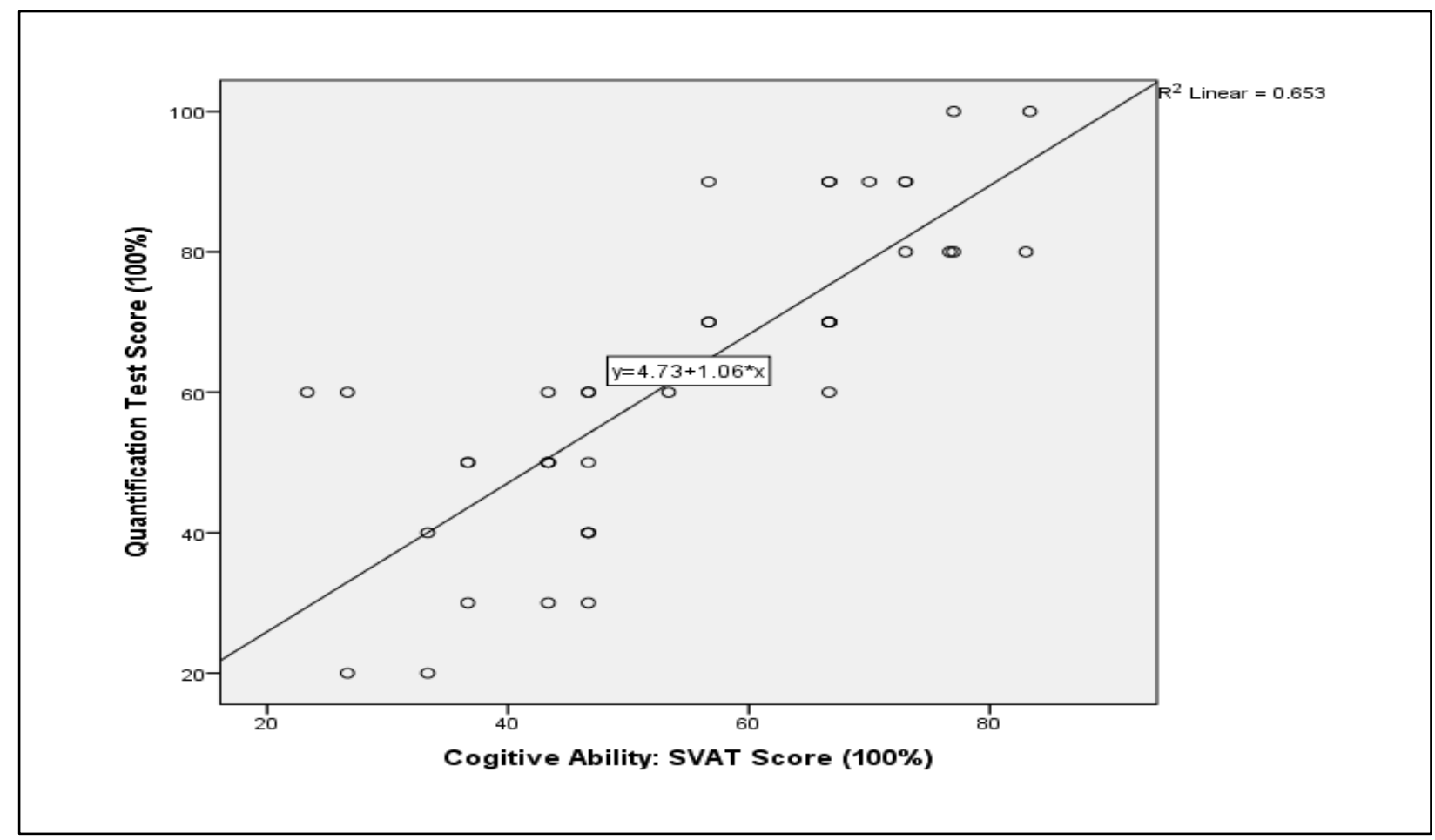

Figure 1. Linear Relationship

Subsequently, the present study uses Pearson correlation analysis to identify the strength and magnitude of the relationship between the SVAT and CQT scores. Interestingly, as shown in Table 3, the Correlation between students' spatial visualisation ability (SVA) and their performance on the construction quantification is a statistically significant positive relationship ( $r=0.808, p<0.05)$. Therefore, the finding concluded that the SVAT score corresponds to the construction quantification achievement.

Table 3. Summary of Research Finding

\begin{tabular}{|c|c|c|c|}
\hline \multicolumn{4}{|c|}{ Correlations } \\
\hline & & CQT Score & SVAT Score \\
\hline \multirow[t]{3}{*}{ CQT Score } & $\begin{array}{l}\text { Pearson } \\
\text { Correlation }\end{array}$ & 1 & $.808^{* *}$ \\
\hline & Sig. (2-tailed) & & .000 \\
\hline & $N$ & 40 & 40 \\
\hline \multirow[t]{3}{*}{ SVAT Score } & \begin{tabular}{|l|} 
Pearson \\
Correlation
\end{tabular} & $.808^{* *}$ & 1 \\
\hline & Sig. (2-tailed) & .000 & \\
\hline & $N$ & 40 & 40 \\
\hline
\end{tabular}

** Correlation significant at the 0.01 level (2-tailed).

In addition, educational theorists also believed that integrating cognitive factors such as spatial ability and the nature of specific characteristics such as different demographics (age and experience) in learning influences students' achievement as it was a great concern to enhance the achievement of students with lower spatial abilities (Salthouse, Babcock, Skovronek, Mitchell \& Palmon, 1990). Nevertheless, findings derived from a previous study claimed that mostly the findings suggested non-significant differences exist for spatial visualisation abilities between males and females (Morris, 2018). Furthermore, previous 
research showed that many findings contradict one another when considering different characteristics of SVA and demographics.

Therefore, in this present study, a T-Test was used to compare the differences level of SVAT and CQT scores between two groups (gender and age differences). The findings obtained in this present study were as follows:

1. SVAT scores between male and female learners

The test of equality of variances (Levene's test) shows that the variances of SVAT scores for the two groups (gender) are equal ( $p$-value $=0.85>0.05)$. Based on the results in the row labelled equal variances assumed, there is no significance in SVAT scores between male and female learners as shown by the $p$-value $=0.616>0.05$ ). Based on the group statistics table, the mean SVAT scores for males are higher than for females. On average, SVAT scores for male students' were higher ( $M=55.67, \mathrm{SD}=$ $14.23)$ than female learners $(M=52.97, S D=19.15)$. However this difference is not significant $\mathrm{t}(38)=0.506, \mathrm{p}=0.616$.

2. SVAT scores between category 19 to 20 and 21 to 22 years old learners The test of equality of variances (Levene's test) shows that the variances of SVAT scores for the two groups (age) are equal ( $p$-value $=0.837>0.05$ ). Based on the row labelled equal variances results, there is no significance in SVAT scores between category 19 to 20 and 21 to 22 years old learners as shown by the $p$-value $=0.316>$ 0.05). Based on the group statistics table, the mean SVAT scores for 19 to 20 are lower than category 21 to 22 years old learners. On average, SVAT scores for category 19 to 20 learners were lower $(M=51.76, S D=16.11)$ than age 21 to 22 years old categories $(M=57.14, S D=17.34)$. Yet this difference is not significant $t(38)=-1.017, p=0.316$.

3. CQT scores between male and female learners

The test of equality of variances (Levene's test) shows that the variances of CQT scores for the two groups (gender) are equal ( $p$-value $=0.563>0.05$ ). Based on the results in the row labelled equal variances assumed, there is no significance in CQT scores between male and female learners as shown by the $p$-value $=0.723>0.05$ ). Based on the group statistics table, the mean CQT scores for male is higher than for female. On average, CQT scores for male learners were higher $(M=63.50, S D=20.59)$ than female learners $(M=61.00, S D=23.60)$. Nevertheless this difference is not significant $t(38)=$ $0.357, p=0.723$.

4. CQT scores between age 19 to 20 and 21 to 22 years old learners

The test of equality of variances (Levene's test) shows that the variances of CQT scores for the two groups (age) are equal ( $p$-value $=0.799>0.05$ ). Based on the row labelled equal variances results, there is no significance in CQT scores between category 19 to 20 and 21 to 22 years old learners as shown by the $p$-value $=0.162>0.05$ ). Based on the group statistics table, the mean CQT scores for 19 to 20 are lower than those of 21 to 22 years old. On average, CQT scores for age 19 to 20 learners were lower ( $M=$ $57.62, S D=20.47)$ than category 21 to 22 years old learners $(M=67.37, S D=22.81)$. But this difference is not significant $\mathrm{t}(38)=-1.425, \mathrm{p}=0.162$. 
To summarise, age and gender differences in spatial visualisation ability (SVA) scores and construction quantification achievements were insignificant in this research. Thus, the findings are similar to the Morris (2018) findings but conflict with other research that reported a significant relationship between the research variables.

\section{Conclusion}

This paper attempts to confirm the relationship and effect of different cognitive abilities and demographics on learners' academic achievement. Generally, these core variables were reported in the previous articles to impact the learning and performance framework studies significantly. In this study, these two sets of variables were categorised within different domains and analysed against the construction quantification achievements to verify the natural factors (personal and situational factors) that are assumed to influence the learning and performance of an individual. When formulating an effective learning and performance framework, addressing the relevant factors to minimise an individual's learning difficulties is beneficial. It is critical to be aware of the critical success factors of learners, especially when dealing with technical education. Likewise, in the quantity surveying programme, each learner must possess technical knowledge for solving problem-solving tasks as the task requires visualising and calculating the approximate cost of the whole project from the 2D construction drawings. Based on the findings of this study, the positive result derived from the analysis and the review of the literature indicated that the SVA could provide practical value in helping a novice who is poor at visualising things and struggled to estimate quantities from the conventional 2D representation construction drawing. It seems that it is value-added when learners possess a high level of SVA because it will help them understand and perform better during the construction quantification learning. Especially for beginners that possess limited knowledge and experience in construction technology practices. As a result, the positive indicator of spatial visualisation ability (SVA) towards the learners' construction quantification achievement obtained in this study later can fit into the best practices guideline to promote better academic achievement and anticipated skill requirements among quantity surveying graduates.

Additionally, the second question raised in this study is to determine the significant difference of other critical indicators or specific constructs relevant to the learning and performance guidelines for the fundamental course of construction quantification. For example, in dealing with the construction quantification achievements of learners, it seems crucial to analyse whether there is a significant difference in SVAT and CQT scores between groups of students with different demographics (gender and age). Similarly, the positive findings obtained via this second objective could contribute a reliable indicator to enhance the learning and performance of learners in quantity surveying education. However, in this preliminary study, the findings for the comparison mean differences between the two groups of different demographics indicated no difference exists between gender and age categories to the SVAT and the CQT scores. Therefore, the evidence shows that demographic profile differences were accepted to have not contributed significantly to the learners' SVAT and CQT achievements because gender and age construct has a lower effect in becoming a possible predictor of success to the construction quantification achievement. Therefore, in the future learning strategies of construction quantification, the demographic profile differences indicator can be excluded from the best practices guideline as it is not the critical factor when predicting the SVAT and CQT achievement. However, it would be interesting if the same indicator of 
demographics could be further tested in future research to look into the other findings possibilities. More research across gender and age groups from other samples is needed to confirm the validity of these present findings.

\section{Corresponding Author}

Norhafizah Yusop

Department of Built Environment Studies and Technology, Faculty of Architecture, Planning and Surveying, Universiti Teknologi MARA, Perak Branch, 32610 Seri Iskandar, Perak, Malaysia.

Email: norha158@uitm.edu.my

\section{References}

Ali, K. N., Mustaffa, N. E, Keat, Q. J. \& Enegbuma, W. I. (2016). Building information modelling (BIM) educational framework for quantity surveying students: The Malaysian perspective. Journal of Information Technology in Construction (ITCon), 21, 140-151. https://www.itcon.org/2016/9

Arslan, A. R., \& Dazkir, S. S. (2017). Technical drafting and mental visualisation in interior Architecture education. International Journal for the Scholarship of Teaching and Learning, 11(2), 15. https://doi.org/10.20429/ijsotl.2017.110215

Atan, L. (1980). Pedagogi kaedah am mengajar (Edisi pertama). Kuala Lumpur: Fajar Bakti Sdn. Bhd.

Ben-Chaim, D., Lappan, G., \& Houang, R. T. (1986). Development and analysis of a spatial visualisation test for middle school boys and girls. Perceptual and Motor Skills, 63, 659669. https://doi.org/10.2466/pms.1986.63.2.659

Börner, K., Maltese, A., Balliet, R. N., \& Heimlich, J. (2016). Investigating aspects of data visualisation literacy using 20 information visualisations and 273 science museum visitors. Information Visualisation, 15(3), 198-213. https://doi.org/10.1177/1473871615594652.

Carroll, J. B. (1993). Human cognitive abilities. Press Syndicate of the University of Cambridge, 327-341. Retrieved from https://doi.org/10.1017/СВ09780511571312.

Cassidy, S. (2004). Learning styles: An overview of theories, models, and measures. Educational Psychology, 24(4), 419-444. https://doi.org/10.1080/0144341042000228834

Fortune, C., \& Skitmore, M. (1993). The identification and classification of the skills required for the collection and transfer of design information. International Council for Building Research Studies and Documentation, pp. 75-85, Lisbon, Portugal. Retrieved from http://eprints.qut.edu.au/archive/00004516.

Fortune, C., \& Skitmore, M. (1994). Quantification skills in the construction industry. Construction Management and Economics, 12(1), 79-88. https://doi.org/10.1080/01446199400000009

Galesic, M., \& Garcia-Retamero, R. (2011). Graph literacy: A cross-cultural comparison. Medical Decision Making, 31(3), 444-457. https://doi.org/10.1177/0272989X10373805

Golledge, R. G. \& Stimson, R. J. (1997). Spatial behaviour. A geographic perspective. 156-157. New York: The Guilford Press.

Hunter, J. E. (1986). Cognitive ability, cognitive aptitudes, job knowledge, and job performance. Journal of vocational behaviour, 29(3), 340-362. 
https://doi.org/10.1016/0001-8791(86)90013-8

Inan, F. A., \& Lowther, D. L. (2010). Factors affecting technology integration in K-12 classrooms: A path model. Educational Technology Research and Development, 58(2), 137-154. https://doi.org/10.1007/s11423-009-9132-y

Lee, S., Kim, S. H., \& Kwon, B. C. (2017). VLAT: Development of a Visualisation Literacy Assessment Test. IEEE transactions on visualisation and computer graphics, 23(1), 551560. DOI: 10.1109/TVCG.2016.2598920

McDonnell, F. P. (2010). The relevance of teaching traditional measurement techniques to undergraduate quantity surveying students. Journal for Education in the Built Environment, 1-15. Retrieved from http://arrow.dit.ie/beschrecart/20/.

McGee, M. G. (1979). Human spatial abilities: Psychometric studies and environmental, genetic, hormonal, and neurological influences. Psychological Bulletin, 86(5), 889-918. http://dx.doi.org/10.1037/0033-2909.86.5.889

Merchant, Z., Goetz, E. T., Keeney-Kennicutt, W., Cifuentes, L., Kwok, O. M., \& Davis, T. J. (2013). Exploring 3-D virtual reality technology for spatial ability and chemistry achievement. Journal of Computer Assisted Learning, 29(6), 579-590. https://doi.org/10.1111/jcal.12018

Mohd Derus, M., Mohd Yunus, O. \& Saberi, M. H. (2009) In Search of Competencies of an Exceptional QS in Public Entity: Building A Theoretical Foundation. Proceeding of Seminar Alam Bina II, Faculty of Architecture, Planning and Surveying, Universiti Teknologi MARA Perak (UiTM). Malaysia. Retrieved from https://mpra.ub.unimuenchen.de/id/eprint/19048

Mokhtar, F., \& Din, S. C. (2013). Spatial ability test as a predictor to assess students 3D computer animation academic performance among university undergraduates in Malaysia. In ICERI2013 Proceedings (pp. 4024-4032). IATED.

Morris, S. W. (2018). The Effect of Gender on Spatial Ability and Spatial Reasoning among Students in Grades 2-8. ProQuest LLC.

Novak, J. D. (2010). Learning, creating, and using knowledge: Concept maps as facilitative tools in schools and corporations. Routledge.

Olkun, S. (2003). Making connections: Improving spatial abilities with engineering drawing activities. International Journal of Mathematics Teaching and Learning, 3(1),1-10. Retrieved from http://www.ex.ac.uk/cimt/ijmtl/ijabout.htm

Osman, J., Mazlina, S., Khuzzan, S., \& Razaksapian, A. (2015). Building Information Modelling: Proposed adoption model for Quantity Surveying firms. no. June, 151-165. Retrieved from fstm.kuis.edu.my/icits/proceeding/fullpapers/IC-ITS\%202015\%20 \%20IT\%20056.pdf

Park, S. S., \& Yoon, S. Y. (2012). Assessing Korean Middle School Students' Spatial Ability: The Relationship with Mathematics, Gender, and Grade. Research in Mathematical Education, 16(2), 91-106. https://doi.org/10.7468/jksmed.2012.16.2.091

Paivio, A. (1990). Mental representations: A dual coding approach. Oxford. England: Oxford University Press.

Ramful, A., \& Lowrie, T. (2015). Spatial Visualisation and Cognitive Style: How Do Gender Differences Play Out?. Mathematics Education Research Group of Australasia, 508-515. Retrieved from https://files.eric.ed.gov/fulltext/ED572512.pdf

Robichaux, R. R., \& Guarino, A. J. (2000). Predictors of visualisation: A structural equation model. Paper presented at the Annual Meeting of the Mid-South Educational Research Association, Bowling Green, KY. Retrieved from 
https://files.eric.ed.gov/fulltext/ED451143.pdf

Rozimah, B. (2014). Kesan interaksi atribut persembahan multimedia, gaya kognitif, peringkat pengajian dan bidang pengajian ke atas daya ingatan visual pelajar Institusi Pengajian Tinggi. Unpublished doctoral dissertation, Universiti Utara Malaysia.

Salthouse, T. A., Babcock, R. L., Skovronek, E., Mitchell, D. R., \& Palmon, R. (1990). Age and experience effects in spatial visualisation. Developmental Psychology, 26(1), 128. https://psycnet.apa.org/doi/10.1037/0012-1649.26.1.128

Wang, H. C., Chang, C. Y., \& Li, T. Y. (2007) The Comparative Efficacy of 2D-Versus 3D-Based Media Design for Influencing Spatial Visualisation Skills. Computers in Human Behavior, 23(4), 1943-1957. https://doi.org/10.1016/j.chb.2006.02.004

Witkin, H. A. (1973). The role of cognitive style in academic performance and in teacherstudent relations 1 2. ETS Research Bulletin Series, 1973(1), i-58. https://doi.org/10.1002/j.2333-8504.1973.tb00450.x

Witkin, H. A., Moore, C. A., Goodenough, D. R., \& Cox, P. W. (1977). Field-dependent and fieldindependent cognitive styles and their educational implications. Review of educational research, 47, 1-64. https://doi.org/10.3102/00346543047001001 